\title{
Spondylus and Glycymeris bracelets: trade reflections at Neolithic Vinča-Belo Brdo
}

\author{
Vesna Dimitrijević ${ }^{1}$, Boban Tripković ${ }^{2}$ \\ 1 Institute of Regional Geology and Palaeontology, Faculty of Mining and Geology, Serbia \\ vesnadim@beotel.yu \\ 2 Department of Archaeology, Faculty of Philosophy, Serbia \\ B.Tripkovic@f.bg.ac.yu
}

\begin{abstract}
In the provision, production and exchange of prestigious items and materials in prehistoric Europe, marine shell ornaments play important role. The marine shell collection at the VinčaBelo Brdo site is the largest in the central and northern Balkans. More than 300 ornament items manufactured from marine shells have been collected since the first excavations in 1908 up until the most recent campaign. The majority of ornaments were made using recent shells that were obtained through trade with contemporaneous Neolithic communities; few ornaments were made of fossil bivalve shells. Bracelets were the most common type. Two bivalve genera, Spondylus and Glycymeris, were used in their production. These are easily recognizable when complete valves are compared, but difficult to distinguish in highly modified items where shell morphology is obscured. The defining characteristics for shell identification are presented, particularly to differentiate ornaments manufactured from the Spondylus and Glycymeris genera, as well as those made of recent and fossil shells. The possible exchange routes for these are discussed, as well as their diachronic distribution at the Vinča site.

IZVLEČEK - Okraski iz morskih školjk so igrali pomembno vlogo pri pripravi, izdelavi in menjavi prestižnih predmetov in materialov v prazgodovinski Evropi. Zbirka morskih školjk iz najdišča VinčaBelo Brdo je največja na centralnem in severnem Balkanu. Od prvih izkopavanj leta 1908, do danes so našli več kot 300 okrasnih predmetov, izdelanih iz morskih školjk. Večino okrasnih predmetov so izdelali iz recentnih školjk, ki so jih dobili z menjavo s sočasnimi neolitskimi skupnostmi, nekaj pa so jih izdelali iz fosilnih dvolupinskih školjk. Najpogostejše so bile zapestnice. Za njihovo izdelavo so uporabljali dva rodova školjk, Spondylus in Glycymeris. Te rodova sta lahko prepoznavna, če primerjamo cele lupine, težko pa ju razločujemo pri močno spremenjenih predmetih, kjer je školjčna morfologija nejasna. Predstavljamo ključne elemente, ki omogočajo razpoznavo školjk, iz katerih so izdelani okrasni predmeti. Analiziramo poti njihove menjave in diahronično distribucijo na najdišču Vinča.
\end{abstract}

KEY WORDS - Archaeomalacology; Spondylus; Glycymeris; Neolithic; Vinča culture

\section{Introduction}

Marine shell ornaments were recorded at the beginning of Neolithic research in the Central Balkans, in the early $20^{\text {th }}$ century. The famous Vinča excavator Vasić, in an article published after the first excavation season, presented 9 shell bracelets (Vassits 1910). However, in later works, including the four tome Vinča monograph, he never mentioned them again (Vasic 1932; 1936). Similarly, throughout the rest of the century and following the traditional preoccupation with pottery analysis, these exotic items were largely neglected.

Comprehending the importance and role of shell ornaments in the life of prehistoric communities on 
the European continent, noting especially the indications they offer concerning trade and social contacts, we initiated research into the occurrence of marine shells in the Balkans Neolithic, starting with the Starčevo and Vinča cultures (Dimitrijević and Tripković 2003).

In these respects, certainly the most important collection is from the central and largest site of the Vinča culture - Belo Brdo, in the Vinča village. In the impressive $10.5 \mathrm{~m}$ thick section, layers with remains from the Starčevo and Vinča cultures were formed in the continuation from approximately $5500 \mathrm{BC}$ to 4300 BC (Garašanin 1979; Chapman 1981; Stevanović, Jovanović 1996; Gläser 1996), thus covering the time of maximal distribution of Spondylus and other marine shells across the European continent. Changes in the numbers and composition of shell ornaments at Vinča-Belo Brdo are a reflection of processes from the wider region, and may disclose important data for understanding prehistoric European contact networks.

\section{Shell identification, origin problems and the aims of analysis}

Our first insight into the marine shell artifacts from Vinča-Belo Brdo was an assemblage from the 19982001 seasons. Previously, we described 14 bracelet fragments made of Spondylus and directed attention to the origin and distribution of shells of this bivalve genus (Dimitrijević and Tripković 2003). However, during and after the analysis, in the course of continuing excavations, the more complex content of shell collections was revealed: items were manufactured using not only recent shells, but also fossil mollusks, and not only Spondylus shells.

A number of artifacts were made from the shells of another bivalve genus, Glycymeris. Its appearance in the north and central Balkans had not been previously analyzed, nor was its role and distribution within the European continent fully understood. However, its importance in prehistory is shown by an example from the Levant, where it was used, in the course of the Neolithic, Chalcolithic, and the Bronze Age, particularly for ornament production, but also for other purposes, such as the substrata foundations of pavements, or as eye applications on the famous statuette of Ur (Bar-Yosef 1991; 2002).

Glycymeris occurrences are rather numerous in the coastal region of the Eastern Mediterranean and Black
Sea during the Neolithic and Eneolithic. Together with Spondylus, they are the most important marine shells used as ornaments at the sites of Sitagroi and Servia in Macedonia and Greece, as well as at the Durankulak necropolis in eastern Bulgaria (Reese 1987; Karali 1999; Nikolaidou 2003; Todorova 2002). However, the evaluation of its importance is often difficult, since the shells are so greatly modified in the process of the artefact manufacture that identification of Glycymeris and its differentiation from Spondylus is hindered.

At the Durankulak site and necropolis, for example, 1505 shell items are characterized as Spondylus/Glycymeris (Avramova 2002), but only 24 bracelets are specified as made of Glycymeris shell (Todorova 2002.177-186). An example of Gura Baiucului is also illustrative. A bracelet is described as made of Pectunculus, a synonym for Glycymeris (Vlassa 1976. Fig. 14, 11). In later publications the same item is described as a bracelet of Spondylus (Lazarovici and Maxim 1995.154, Fig. 26.1). At Anza, a Neolithic site in Macedonia, all shell bracelets found are described as made of Spondylus (Gimbutas 1976). In fact, at least one specimen is Glycymeris shell, as the distinct morphological features of the Glycymeris hinge and adductor muscle scar are recognizable in its illustration (see Gimbutas 1976.Fig. 215.6). Similarly, the attribution of marine shell artifacts as a priori Spondylus items may be oversimplified evidence at many European inland sites.

If ornament production from marine shells was a unique process in prehistory, with no cultural and chronological differences no matter what species of marine shell is used, than this question of Spondylus/ Glycymeris differentiation could be disregarded. But, there are indications that this is not the case.

In this respect the aims of our paper are:

- to present Vinča-Belo Brdo shell assemblages from the earliest excavation until the most recent campaign;

- to define fossil/non-fossil shell origins;

- to establish identify characteristics for artifacts from different shell species;

- to reconsider the source areas for shell acquisition and probable exchange routes.

\section{Raw material for ornament production - fos- sils or recent ${ }^{1}$ shells?}

Fossils were collected in the Vinča surroundings and brought to the site. Two fragments of fossil clam Lim-

1 Meaning contemporaneous to the Neolithic, i.e. living broadly in the same time as Vinča inhabitants. 
nocardium (= Pannonicardium) are present in the material from Vasić's excavations. One is quadrangular in shape $(2.5 \times 2.5 \mathrm{~cm})$, modified by cutting and scraping (Babovic 198.180, catalogue No. 250). It is identified as brackish clam Pannonicardium dumičici of Pontian (Upper Miocene) age 2 . The other, similar in shape and size $(3.5 \times 3.2 \mathrm{~cm})$ is perforated, and thus clearly modified into a pendant (Fig. 1a). A third fragment of similar shape and size $(4 \times 3.3 \mathrm{~cm})$ was found in the last excavation campaign (Fig. 1b). The question arises that, if fossils were modified into pendants, were other ornament items also made of fossil shells?

Certainly for most Spondylus ornaments, we expect this is not the case. We should consider at least one specimen from Vinča doubtlessly recent: the one analyzed for oxygen isotopic composition (Shackelton and Elderfield 1990) ${ }^{3}$. Should this fact point to the conclusion that all Spondylus items were made of recent and not fossil shells? And should, then, other Spondylus, and especially Glycymeris items, differ from Spondylus items according to their origin?

So, the questions are posed: did the raw material for making ornament objects originate from recent, fossil, or both kinds of shell? The answer is important, because fossil origins indicate acquisition in a nearby region of the site, while recent origins imply longdistance trade relations with contemporaries, as the nearest coastline is more then $500 \mathrm{~km}$ from the Vinča site. This leads us to the necessity of considering fossiliferous sites with marine shells in the region,

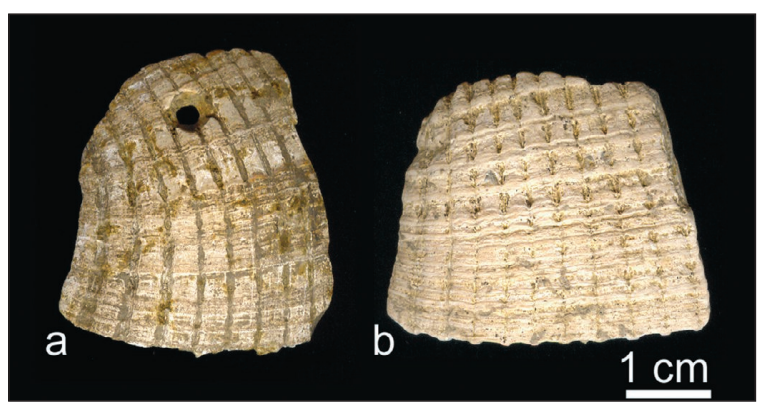

Fig. 1. Worked fragments of Miocene clam Limnocardium: a. perforated specimen excavated by Vasić; b. specimen excavated in 2003. investigating the appearance of the fossils, their availability and convenience as a raw material, and establishing whether it is possible to distinguish them among ornament items from recent shells.

Several sites with exposed marine Miocene deposits rich in fossil mollusk remains are revealed in the surroundings of the Vinča village. The best known are the villages of Višnjica and Slanci, at a distance of 5$7 \mathrm{~km}$ northeast of Vinča, and Rakovica, once a village, but now a part of Belgrade, approximately the same distance to the southeast. Further away, in central, eastern and western Serbia there are other sites rich in nicely preserved fossils of the same age. In total, four fossil species of Glycymeris and one fossil species of Spondylus have been identified in the marine Miocene of Serbia: Glycymeris obtusatus ${ }^{4}$ and Glycymeris pilosus 5 are frequent species in the whole region. Spondylus crassicostata $\mathbf{6}$ is also found on many sites, while occurrences of Glycymeris corobtusata 7 and Glycymeris fichteli 8 are more rare, and found in eastern Serbia (Stevanović 1977; Petkovic 1987). Spondylus gaederopus, a species that is mostly used as a raw material at Neolithic sites in Europe, was present in the Miocene. But in the Miocene deposits of Serbia its presence is not confirmed, although it is known in an adjacent area in Bulgaria (Kojumdgieva and Strachimirov 1960.75-76).

The late Professor Petar Stevanović, who was the most respected authority on Tertiary fossil mollusks in Serbia, identified shells from which two fragmented bracelets from Vinča were made as a fossil Middle Miocene clam Pectunculus pilosus (Babović 1984.127, catalogue No. 235, 237). Pectunculus is the name previously used, but it is now incorporated in the genus Glycymeris (Moore 1969). Likewise, G.pilosus is often treated as the same as G.glycymeris, being of similar morphology, although some taxonomists regard them as distinct species.

The fossil finds of other mollusk species at the site were identified by Stevanović as Cytherea sp., Turritella turis and the previously mentioned Pannonicardium dumičici $i$ (1984.128, catalogue No. 251, 250, 253). These finds show that the Vinča inhabi-

2 Identification was performed by P. Stevanović (Babović 1984.121).

3 The isotopic analyses were performed to establish whether shells for making ornaments in Neolithic originate from Mediterranean or Black Seas. However, if differencies were enough to make distinctions between contemporaneus Mediterranean and Black sea, they would certainly be much greater if a shell originated from much warmer Miocene sea.

4 Cited as Pectunculus obtusatus Partsch in Petkovic 1987.

5 Cited as Pectunculus pilosus in Stevanović 1977; Petković 1987.

6 Cited as Spondylus crassicostata Lamarck in Stevanovic 1977; Petkovic 1987.

7 Cited as Pectunculus (Axinea) corobtusata (Lartsch.) in Petković 1987.

8 Cited as Pectunculus fichteli Deshayes in Petković 1987. 
tants visited different fossiliferous sites in the vicinity to collect fossils, as Pectunculus pilosus, Cytherea sp. and Turritella turis originate from the Middle Miocene marine deposits, while Pannonicardium dumičici comes from the brackish Upper Miocene. Also, tube-like shells of the fossil scaphopod known as Dentalium were used at Vinča as beads (Babović 1984, catalogue No. 238).

However, collecting fossils and even using some of them as ornaments does not indicate that fossils were suitable for any ornament, namely bracelet, production. We think that Stevanovic was wrong when ascribing shells, from which two fragmented bracelets from Vinča were made from fossils. This mistake is not surprising, as Stevanović was a paleontologist, who was aware that marine animals lived in the region in the Miocene, but not thereafter, as the ancient sea withdrew. So, he was apt to look at marine shells as a priori fossils, especially when dealing with species that are represented in regional fossil sites, like species of Glycymeris and Spondylus genera.

Aware of possible trade relationships that could supply Vinča inhabitants with recent shells, or bracelets made of them, as well as of the availability of fossils in the vicinity, we did not reject fossil or recent origins of shells, but looked through the material with both options as possibilities. We found the following criteria for distinguishing recent shells from fossil shells useful:

(1) Ornament item size. The majority of fossil species are excluded as possible raw material for the production of bracelets since their shells are too small. At Vinča, this is the case with Glycymeris obtusatus, G. corobtusata, and G. fichteli. But shells of some fossil species, like Glycymeris pilosus and Spondylus crassicostata, correspond to the size of shells that are used for ornament manufacture.

(2) Shell morphology. When complete shells are compared it is possible to distinguish species of the same genus, i.e. fossils from recent species. Of course, fragments of broken bracelets, and most complete bracelets as well, are far from having all the characteristics of whole shells, and usually offer nothing to distinguish species of the same genus and similar size. An exception may occur when the hinge area is preserved more or less completely, which is sometimes the case with bracelets made of Glycymeris (Todorova 2002.179, Abb. 201). No specimen of this kind has been found at Vinča.
(3) Internal shell structure and color. What remains recognizable in fragmented items is the internal structure of the shell. Growth lines are often visible either in oblique or cross section, and sometimes the color of the shell, whether from the outer shell layer, or inner, or internal. Usually, fossils are discolored and the shell's exterior form is eroded. However, coloration is not an ample argument for discounting fossil origin. Some fossils from the surroundings of Belgrade, especially those from Rakovica sands, are extraordinarily preserved. Complete valves are present, including the finest details of the outer and inner shell layers, as well as their color.

(4) Transparency and elasticity. What remains observable in almost every item, including those strongly modified by ornament production and those severely fragmented, is the transparency and elasticity of the shell. These should reflect a 'fresh' and translucent appearance in recent shells, as opposed to the brittle and opaque appearance in fossil shells, resulting from mineral exchange. Even the best-preserved fossils lack the internal elasticity of recent shells. On the other hand, ornaments made of recent shells may sometimes also be corroded or show some evidence of the process of mineral decomposition.

Consequently, it is not always possible to determine whether an item is made of recent or fossil shell. Another question is whether fossil shells were convenient at all for modifying into ornaments, given their probable lack of elasticity. In an experiment conducted by Miller (2003) to replicate the manufacture of Spondylus amulets, even beach-collected recent shells were too dry and fragile to withstand the manufacturing process, and they tended to break. Furthermore, it is highly improbable that well-preserved fossils were available in sufficient numbers for sustained production. We found no items among the fragmented bracelets from Vinča that could be identified positively as a fossil. There were several fragments which we were uncertain about regarding as of recent or fossil origin, but the majority was positively identified as made of recent shells, thus acquired by trade or some other kind of contact/exchange with contemporaneous communities of the wider region.

\section{Distinguishing parameters for shell identifica- tion: Spondylus or Glycymeris?}

Belonging to two very distant families, Spondylus and Glycymeris shells are easily recognizable. It is 
only because ornament production tends to eliminate as much of the original morphology of the shell as possible that differentiation is problematic. Nevertheless, it is these obscured morphological characteristics we have to address when looking for features which differentiate shells of two genera. To demonstrate the ornaments variability of the two species the particular bracelet fragments found at Vinča have been taken as examples.

Spondylus: description. The shell is massive and consists of two unequal valves. In the hinge area there are large dental sockets and hinge teeth (Fig. $2.1 \mathrm{a}-\mathrm{b})$. There are two equal teeth in each valve, positioned symmetrically on either side of a resilium pit where the internal ligament is placed, with two large sockets for receiving corresponding teeth in the other valve. The shell is milk-white, purple or yellowish-brown and with distinct radial ribs and large, irregular spines (Fig. 2.1c). During the lifetime of the animal it is usually attached by its right valve to a solid substrate. Due to the unequal size of the valves and attachment to the ground, the species exhibits great variability in shape, color and ornamentation. On the inner side a large circular adductor scar is placed posteriorly (Fig. 2.1d). The ventral margin on the inner side is scalloped (Fig. 2.1e).

Spondylus bracelet: description. The bracelets were made of transversal sections of the valve. In the dorsal half of the valve the bracelet band is parallel to the arm of the wearer (Fig. 2.2, 4-7), while the central section curves in a spiral (Fig. $2.3,8$ ) and continues into a vertical position perpendicular to the arm of the wearer (Fig. 2.9-10). The bracelet is thickest in the section made of the dorsal part of the valve, where a hinge arch is incorporated into a bracelet band. Hinge teeth and dental sockets are prominent on some bracelet fragments (Fig. 2.4-5, 7), although mainly only the teeth bases and socket bottoms are left after extensive rubbing of the shell. Some bracelet fragments are cut below the hinge, or the hinge area is so intensively rubbed that no traces of teeth or sockets remain. However, they often bear remnants of umbonal cavity on the inner side of the band (Fig. 2.2, 6). Laterally and toward the ventral side of the valve, the bracelets are much thinner. The purple coloration of the outer shell layer is well preserved in some specimens (Fig. 2.3, 8-10), while in others it is noticeable in traces or is absent. Shell growth lines are also observable on most bracelet fragments both lengthways and in cross-section.

Glycymeris: description. The shell is circular, and valves are similar in size, shape and convexity. The beak (umbo) (Fig. 3.1a) is in the center, and curved inward. The hinge is made of teeth rows (Fig. 3.1c) arranged in straight lines on both sides. The hinge plate is arched. Above it and below the beak is a flat field of triangular shape called area (Fig. 3.1b). On

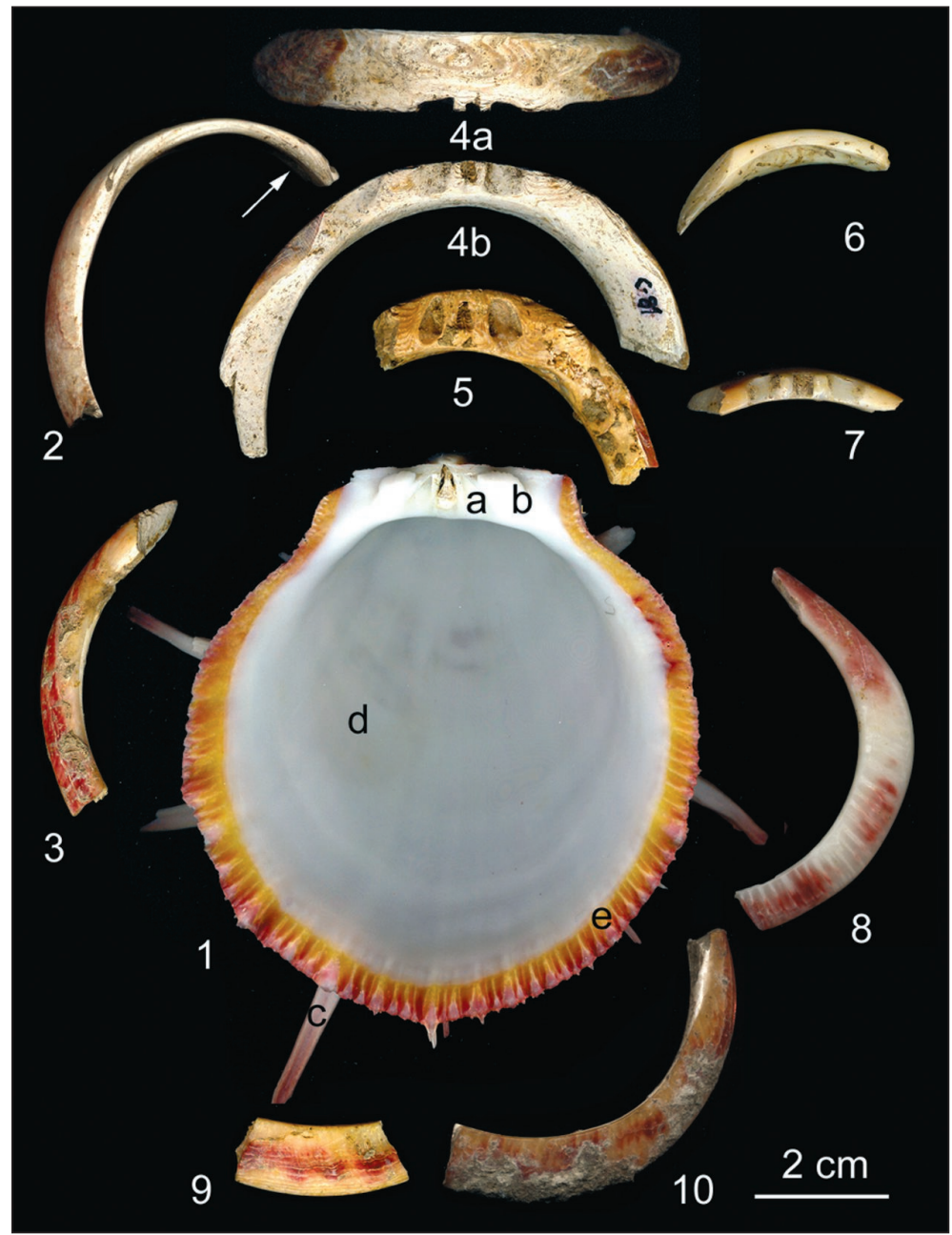

Fig. 2. Spondylus shell and representative bracelet fragments. 1. Spondylus sp., recent, inner side of the left valve, a. socket, b. cardinal tooth, $c$. spine, d. adductor scar, e. ventral margin; 2, 7 and 10. bracelet fragments excavated by Vasić; 3 . bracelet fragment excavated in 1982; 8. bracelet fragment excavated in 2001; 4, 5, 6 and 9. bracelet fragments excavated in 2002; 2 . the arrow points to the preserved bottom of the umbonal cavity. 
the inner side of valves, adductor scars (Fig. 3.1d) are circular and positioned near the anterior and posterior margins. The inner margin is crenulated (Fig. 3.1e). Fine costate ornamentation and brown mottling characterize the outer shell.

Glycymeris: bracelet description. A common type of bracelet is made when a valve is cut along its maximal diameter, including the umbilical part. The shape obtained is a bracelet with a circular outline and a triangular bump on one side (Figs. 3.3, 4, 7; Fig. 4). The beak is grounded and the triangular field flattened. Often a perforation is drilled in the middle of this area (Fig. 3.4-5). The umbonal cavity is observable on the inner side of the band (Figs. 3.2, 4-5). Sets of hinge teeth are sometimes observable, but usually only notches remain in their place, since this part of the valve is mostly ground down. The transversal section of the bracelet band changes in relation to the part of the valve from which it is made: the bracelet portion made of the ventral part of the valve is oblate, i.e. elliptical, with the larger diameter perpendicular to the arm of the wearer (Fig. 3.8-10), while toward the lateral portion of the valve it changes first in circular outline,

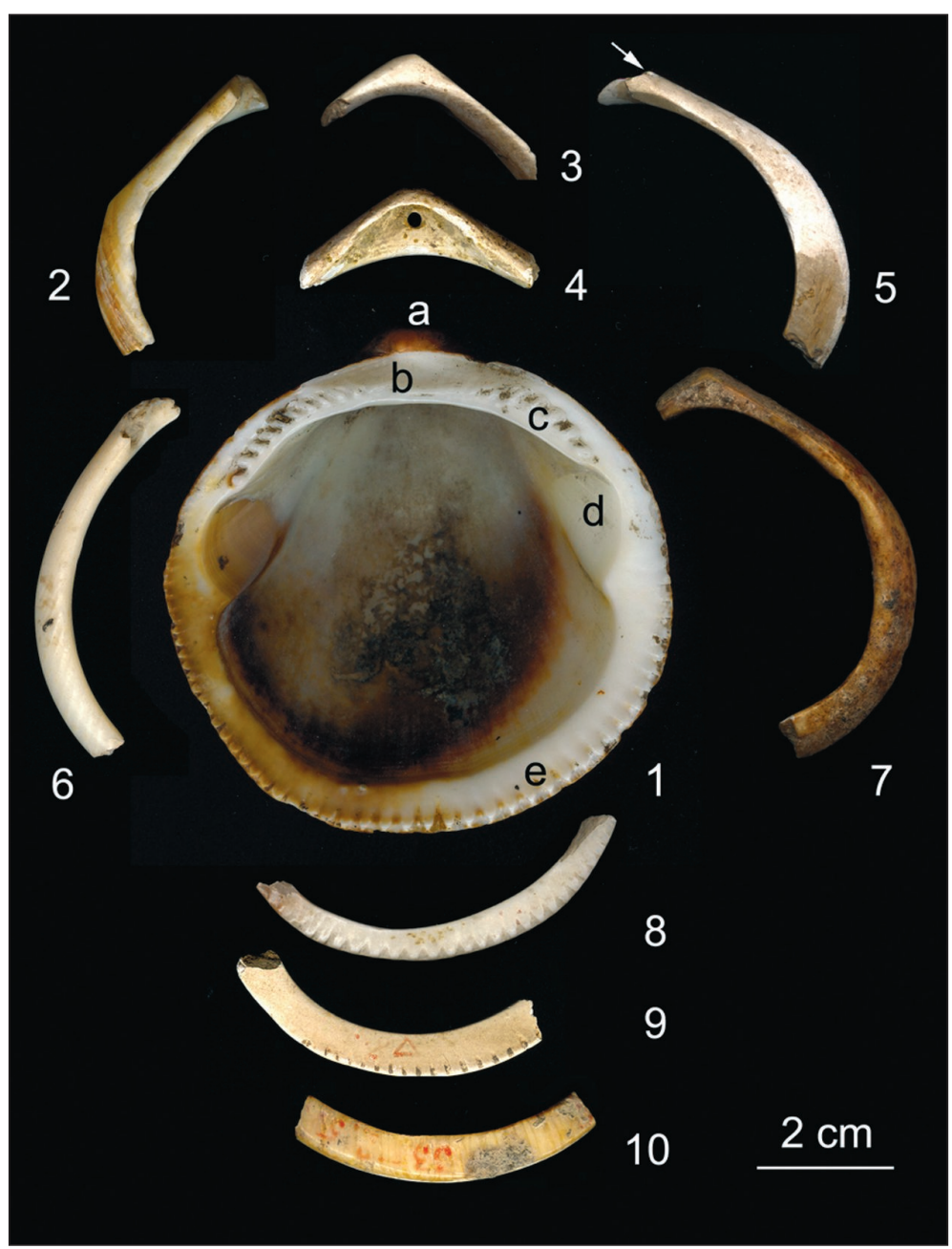

Fig. 3. Glycymeris shell and representative bracelet fragments. 1. Glycymeris glycymeris, recent, inner side of the right valve, a. beak, b. area, c. teeth, d. adductor scar, e. crenulated inner margin; 2-10. bracelet fragments excavated by Vasic; 5 . the arrow points to the remnant of the umbonal cavity; 2 and 6. mirror view. then in elliptical, with the larger diameter parallel to the arm (Fig. 3.6). Fragments made of the ventral portion of the valve often bear traces of crenulations of the inner margin. They may be in the shape of clearly outlined connected triangles (Fig. 3.8), when the rubbing of the valve was not very intensive, or in the shape of parallel notches (Fig. 3.9), resulting from grinding away the inner sculpture of the shell. Some fragments preserve the outer shell layer, which is characterized by a light brown, sometimes brownpurple, color, and fine reticule (Fig. 3.10).

To distinguish between Spondylus and Glycymeris items, we find recognizable the following natural features:

(1) Valve outline. When complete bracelets are in question it is easy to make a distinction: Glycymeris products have a triangular bump on one side, a cir- cular outline and a quite symmetrical and regular form (Figs. 3.7, 4). Spondylus bracelets are usually more massive (Fig. 2.4), oval or elliptical in outline (Fig. 2.2), and often have an asymmetrical and irregular form.

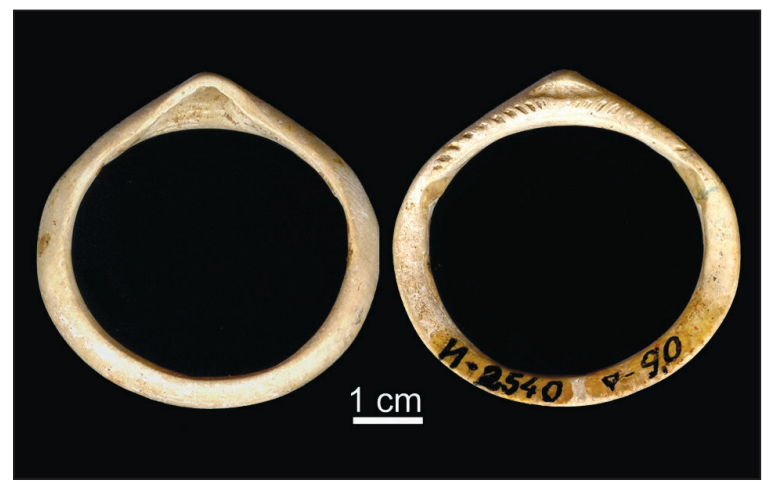

Fig. 4. Glycymeris bracelet from Vinča, Vasić's excavation, depth $9 \mathrm{~m}$. 


\begin{tabular}{|c|c|c|}
\hline $\begin{array}{l}\text { depth } \\
\text { (m) }\end{array}$ & Spondylus & Glycymeris \\
\hline 1 & o & \\
\hline 1,5 & $0 \circ 0$ & \\
\hline 2 & 000000000000 & o \\
\hline 2,5 & 00000000000000000 & 000 \\
\hline 3 & 000000 & \\
\hline 3,5 & 0000000 & 00000 \\
\hline 4 & & o \\
\hline 4,5 & & 00 \\
\hline 5 & & 000 \\
\hline 5,5 & 000 & 00 \\
\hline 6 & 0000 & 0000000 \\
\hline 6,5 & & 00 \\
\hline 7 & 0000 & \\
\hline 7,5 & o & $0 \circ 0$ \\
\hline 8 & & 000000 \\
\hline 8,5 & 0 & 000000 \\
\hline 9 & & 00000 \\
\hline 9,5 & & \\
\hline
\end{tabular}

Fig. 5. Spondylus and Glycymeris ornaments from 1908-1934 excavations distributed by depth.

(2) Shell morphology - hinge area. When the hinge, or part of the hinge arch with its teeth is preserved on the bracelet fragment, it is possible to distinguish small, regular denticules of Glycymeris (Fig. 4), and the large and few teeth and dental sockets of Spondylus (Fig. 2.4-5, 7). In Glycymeris bracelet fragments made of the umbilical part of the valve, there is a recess positioned below this area (Fig. 3.2, 4-5), while Spondylus bracelet fragments made of the umbilical part of the valve are usually of regular circumference and the bracelet lies along the arm by its entire width. A recess positioned below the hinge arch sometimes exists in Spondylus bracelets, too, but its shape is irregular and often appears as a sort of scar on the inner part of the bracelet band (Fig. 2.6).

(3) Shell morphology - middle valve and adductor scars. Glycymeris bracelet fragments made of the middle part of the valve show an even and regular change of bracelet band circumference from the vertical to the horizontal, while they are usually of quite irregular circumference band change in Spondylus fragments. When the adductor scar is preserved in a bracelet fragment made of a Glycymeris valve it has a regular circular outline, close to the valve margin and below the hinge arch (Fig. 4). The adductor scar is shallower, undifferentiated in outline, and positioned away from the hinge area and margin of the valve in Spondylus. Consequently, it is rarely preserved in bracelet fragments, and more often in amulets (Fig. 7.1b).

(4) Shell morphology - ventral valve. Fragments made of the ventral part of a valve, when not overly rubbed, are rather easy to distinguish. In Glycymeris bracelet fragments there are characteristic rows of triangles on the valve margin (Fig. 3.8). When the item is polished, only notches remain from the original triangles (Fig. 3.9), or they disappear completely. Similar notches are found also in the ventral margin of the inner side of the valve in Spondylus fragments. In Glycymeris fragments, these notches are evenly distributed, while in Spondylus they are more irregular, but confusion is still possible.

5 Inner structure. This helps in some instances, but may cause confusion and may be unrecognizable in small and intensively modified fragments. Generally, growth lines are more regular and evenly distributed in Glycymeris, while in Spondylus they are often uneven and sometimes waved, especially near the ventral margin of the valve.

6 Color. Although it is often looked to first to help differentiation, color may also confuse. An intense purple color indicates Spondylus, but not all Spondylus fragments are intensely colored, and some fragments lack such color completely, and are rather milk-white or yellowish. Also, some Glycymeris fragments show traces of a brown, reddish, and sometimes even purple color.

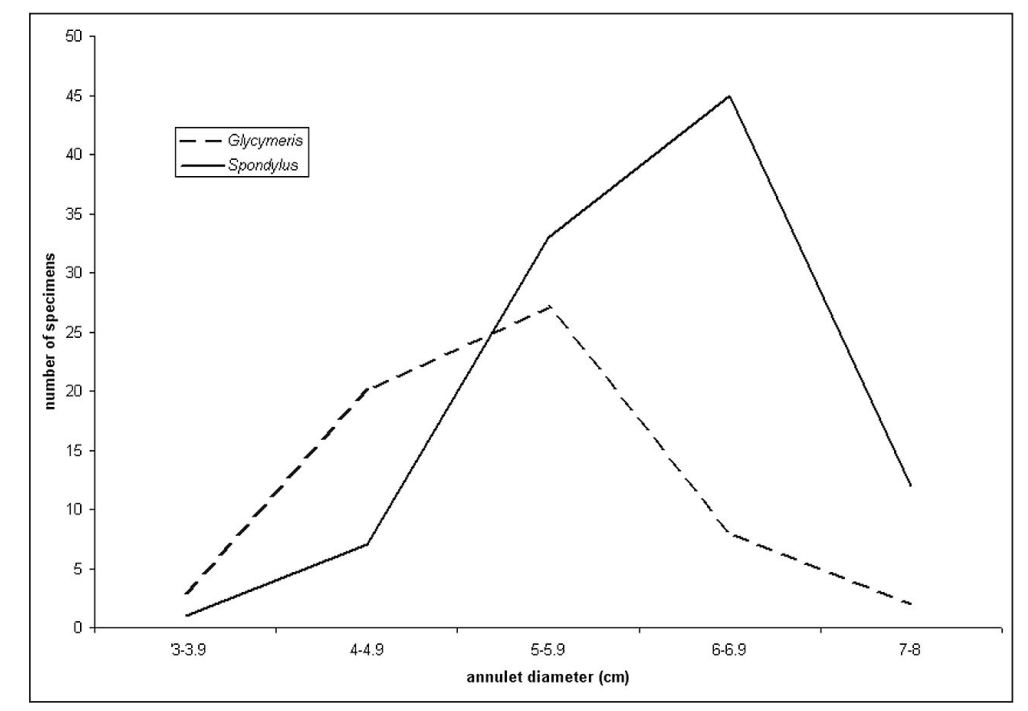

Fig. 6. Inner diameter of bracelets from Vinča. Measurements have been taken of specimens preserved with a length of more than $5 \mathrm{~cm}$. 


\section{Vinča shell ornaments}

The number of marine shell artifacts from the Vinča site to be presented here is 307 (Tab. 1)9. Most of these ornaments are made of recent marine bivalves, but there are also four pieces made of fossil shell, all belonging to the Miocene genus Limnocardium. Fossils that are not recognizably modified in order to make an ornament, shells of other marine organisms, like Dentalium, and mollusks of non-marine origin are not presented here.

Among recent marine bivalves, two genera are identified: Spondylus and Glycymeris. 169 items were made of Spondylus, and 94 of Glycymeris shells. Identification of the bivalve genus was not possible in 41 cases, due to the high degree of modification obliterating morphological features. There were 19 specimens belonging to a separate bivalve genus of massive valves, but small dimensions (mean $10 \times 8$ $\mathrm{mm}$ ); the majority of which (17) are found in the collection of the National Museum in Belgrade, strung through a double perforation in each on a single rope, and with a label indicating they were found at a depth of $3.80 \mathrm{~m}$.

Spondylus and Glycymeris items are present throughout the duration of the settlement at Belo Brdo, although their number varied considerably. This is shown by the distribution of finds collected during the excavation campaigns from 1908 to 1934, when the whole cultural layer to a depth of $9.5 \mathrm{~m}$ was explored, from the latest to the earliest horizons. Glycymeris items are abundant in the lower part of the settlement sequence. of 46 finds for which depth is known ${ }^{10}, 16$ specimens originate from a depth of 9.5-8 $\mathrm{m}$. Above $4 \mathrm{~m}$, there are only 9 Glycymeris

items. Conversely, there is only one Spondylus find from the earliest phase of the settlement. They appear in larger numbers only when the number of Glycymeris finds begins to gradually decrease, while they are most numerous above $4 \mathrm{~m}$.

In the second and the third phases of research, the upper layers of the sequence were excavated (Vinča D). Among 72 items collected, 60 were made of Spondylus shells, 8 of Glycymeris, and 3 items were unidentifiable. It would be important to establish whether chronological differences in the frequency of Spondylus and Glycymeris products simply characterize the Vinča site, or if it is indicative of the overall use of marine goods in the region. On the basis of the current state of published data from the other sites of the Vinča culture, it is not possible to confirm this pattern of chronological change, since these two genera were not differentiated in any of the existing reports. Still, it is highly probable that in the central and northern Balkans, Glycymeris items were present along with those of Spondylus, as evidenced by bracelet finds from the necropolis at Botoš (Petrović 1997.33) and the settlement of Potporanj-Kremenjak (Rašajski 2002.29).11

At present, one can only compare the frequency of Spondylus and Glycymeris finds from sites in the coastal regions of the Aegean and Black Seas. For example, in Sitagroi (Greece), items of both genera appear in the course of phases I-V of the settlement, but are only numerous in phases II and III (Shackleton 2003.361-362; Nikolaidou 2003.333).12 The important observation is that items made of both bivalve genera are approximately equally represented in phase II, while a strong preference for Spondylus became established in phase III (Shackleton 2003. 362).

\begin{tabular}{|lcccc|}
\hline Excavation & Spondylus & Glycymeris & $\begin{array}{c}\text { Recent bivalves } \\
\text { indet. }\end{array}$ & $\begin{array}{c}\text { Fossil } \\
\text { Limnocardium }\end{array}$ \\
\hline $1908-1934$ & 109 & 86 & 38 & 2 \\
\hline $1978-1986$ & 6 & 2 & 2 & 0 \\
\hline $1998-2003$ & 54 & 6 & 1 & 1 \\
\hline Sum & 169 & 94 & 41 & 3 \\
\hline
\end{tabular}

Bracelets are the dominant type of ornament among marine shell finds at the Vinča culture sites; they constitute almost $90 \%$ of all ornament types.

The identification of annulets as bracelets needs some explanation. They
Tab. 1. The number of the marine shell ornaments by taxonomic identification.

9 The analysed finds are stored in the Archaeological collection of the Phylosophical faculty in Belgrade, National museum in Belgrade (1908-1934 excavations), and Museum of Vinča near Belgrade (1978-1986 and 1998-2003 excavations). In addition, a part of the collection from the first research campaigne (1908-1934) is stored at the Birmingham Museum and Art Gallery; approximately 30\% of artifacts in Birmingham are made of Glycymeris (after Shackleton 2003.364).

10 Depth data are written on the specimens; in few cases number is not readible.

11 They are described as Spondylus bracelets, but distinct features of Glycymeris shell are observable on the illustrations.

12 Phase II is dated 5200-4600 cal. BC, phase III 4600-3500 cal. BC, which means that those two phases correspond roughly to complite Vinča sequence. 
might have been used not only as bracelets, but also as hair ornaments and on cloth garments, or anklets. Indeed, the diameters of annulets are sometimes so small that they might have been worn by children, or put on the arm in childhood and never taken off (Gaydarska et al. 2004.24). However, their common usage as bracelets is shown through grave goods, mainly in the region of the Black Sea (Todorova 2002; $A v$ ramova 2002), and indirectly in figurines with bracelet representations (Kalicz and Szénászky 2001.42, Fig. 14). Some of the latter are also found at Vinča (Vasić 1936.XXVII).

Most of the amulets from Vinča have an interior diameter greater than 4 cm (Fig. 6) and were most probably worn around as bracelets. The greater number of Glycymeris bracelets have an interior diameter of 5-6 cm, and only one reaches $8 \mathrm{~cm}$. The bracelet with the smallest diameter (3.9 $\mathrm{cm}$ ) is also the only complete example (Fig. 4).

Most Spondylus bracelets have a rather large diameter. Only eight items have a reconstructed interior diameter smaller than $5 \mathrm{~cm}$ (Fig. 6). In most specimens, bracelet bands are of variable volume, sometimes very massive, exceeding the width of the band by of almost $2 \mathrm{~cm}$ in several items, and thickness of $1 \mathrm{~cm}$ in one item.

Other Spondylus ornaments were also found: buttons, beads, and probably garments (Fig. 7). The morphological features of the bivalve genus are not observable in buttons and beads, but the internal texture, as well as the massive volume of the shell, point to Spondylus, and not Glycymeris. In a garment the adductor scar outline and position indicate Spondylus (Fig. 7.1b). The garment is perforated, and it is broken in the line of two marginal openings. The break was lightly rubbed, so it was used, or it was intended to be used after the breakage.

Perforations on bracelet fragments show that they were used as pendants, garments, or, possibly, parts of composite bracelets, probably after breakage. There are 41 bracelet fragments with a single perforation, and seven with two or more perforations. In the majority of perforated Glycymeris pieces, the opening is positioned below the umbo (Fig. 3.4), or, when it was broken at the umbo, towards the end of the piece, but still within the umbonal cavity (Fig. 8.3-6, 9, 10). Similarly, fragmented Spondylus items are often perforated at the remnant of the umbonal cavity (Fig. 8.7, 12, 16). More rarely, other parts of bracelet band are also perforated (Fig. 8.8, 11, 1315). It is not always certain whether perforations were made before or after breakage, because openings for hanging pendants could be made on the bracelets; or annulets of small diameter might be perforated for wearing as pendants or brooches on garments. Examples of such annulets are known from Botoš (Petrović 1997.33). Probably the majority of these openings were made after breakage in order to prolong the use of the ornament. This is indicated by their symmetrical (Fig. 8.12-13) or brunt position (Fig. 8.1-11, 14-16), and by attempts at drilling observed on at least four items. Items with two openings also confirm a second modification of broken artifacts, especially when openings are positioned at two opposite ends. In one example, the two openings are on different planes, one parallel to the band of bracelet, and another perpendicular to it (Fig. $8.13 \mathrm{a}-\mathrm{b})$. They could be linked by strings to make a composite bracelet, or worn as brooches. Efforts to polish breakages were not made on these twice modified artifacts, except in one case (Fig. 8.14). 
Ornaments made from raw materials other than shell are also found at Vinča, (probably with the intension of imitating shell) and include stone (Vasić 1932.38, Pl. 15, Fig. 62; Antonović 1992.17-18, Pl. 8.5; 2003. 68, Fig. 46.5), bone and pottery (Srejović and Jovanović 1959). Stone bracelets are made mostly of white stone, resembling the milk-white color of the inner side of Spondylus shells. The most important in this respect is a marble item (Vasic 1932.38, Pl. 15, Fig. 62; Antonović 1992.17-18, Pl. 8.5; 2003.68, Fig. 46.5) very similar to the Spondylus garment shown in Fig. 7.1. The traces of red color on its surface were possibly left to imitate the Spondylus shell color.

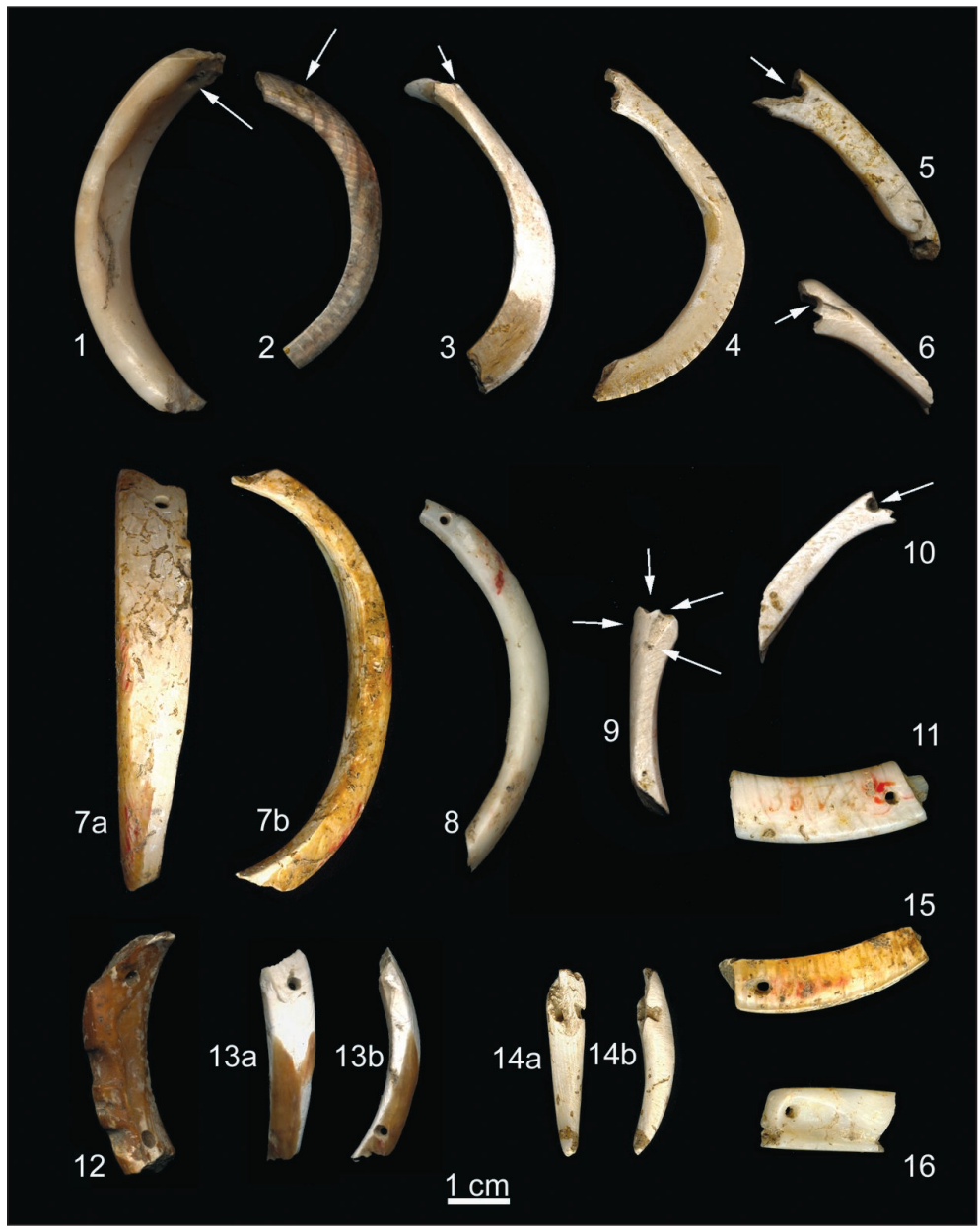

Fig. 8. Fragments of bracelets with perforations. 1. Spondylus bracelet fragment, a remnant of the umbilical depression is visible on the inner side, an arrow points to an opening; 2. Glycymeris bracelet fragment, an arrow points to an opening; 3. Glycymeris bracelet fragment, opening observable at the breakage; 5, 6, 10. Glycymeris bracelet fragments, arrows point to openings positioned within the umbonal cavity; 7. Spondylus bracelet fragment, opening observable at the top of the fragment (7a); 8. Spondylus bracelet fragment, opening observable at the top of the fragment; 9. Glycymeris bracelet fragment, arrows point to two openings positioned within the umbonal cavity and at the line of breakage, and two lower, unfinished perforations; 11, 15. Spondylus bracelet fragments, ventral portion of the valve; 12. Spondylus bracelet fragment, two symmetrical perforations are observable; 13. Spondylus bracelet fragment, two openings are observable at the opposite ends of the fragment, axes of the openings perpendicular to each other; 14. bracelet fragment with one broken perforation and one unfinished perforation on one end, and pointed opposite end; 16. Spondylus bracelet fragments, remnant of the umbilical depression and opening observable.
A bone bracelet (Fig. 9.2) may be regarded as a replica of a shell bracelet, since its shape imitates the shape of a Glycymeris bracelet shell, where a bracelet band changes its position in relation to the arm from perpendicular to parallel. It is made from the bone of a large mammal and is highly polished. In this same way, another bone item (Fig. 9.1) is very similar to shell annulets modified a second time into pendants.

A single fragment of a clay bracelet was found at a depth of $9.2 \mathrm{~m}$ (Fig. 9.3). Bracelets of other materials, but similar to shell bracelets, are found at other sites of the Vinča culture: at Anza (Gimbutas 1976), Divostin (McPherron 1988.329-330), Botoš (Chapman 1981.456-457, Tab. 19-20), Selevac (Tringham and Krstic 1990) and many other sites (see Chapman 1981).

\section{Spondylus and Glycymeris ex- change routes}

European finds of Spondylus shell are traditionally considered to have originated from the Mediterranean Sea (Childe 1927; 1957; Theocharis 1973; Willms 1985; Séfériadès 1995; 1995b; 2000; Müller 1997.8; Kalicz and Szénászky 2001.46; Dimitrijević and Tripkovic 2003). Shells, as well as occasional finds of ornaments, have been found in the coastal areas of the Aegean and Adriatic Seas as early as the end of the $7^{\text {th }}$ millennium BC (Müller, Herrera and Knossalla 1996.84-85; Müller 1997). In addition, strontium isotope analyses of samples of Spondylus shells from several sites (Renfrew and Shackleton 1979; Shackleton and 


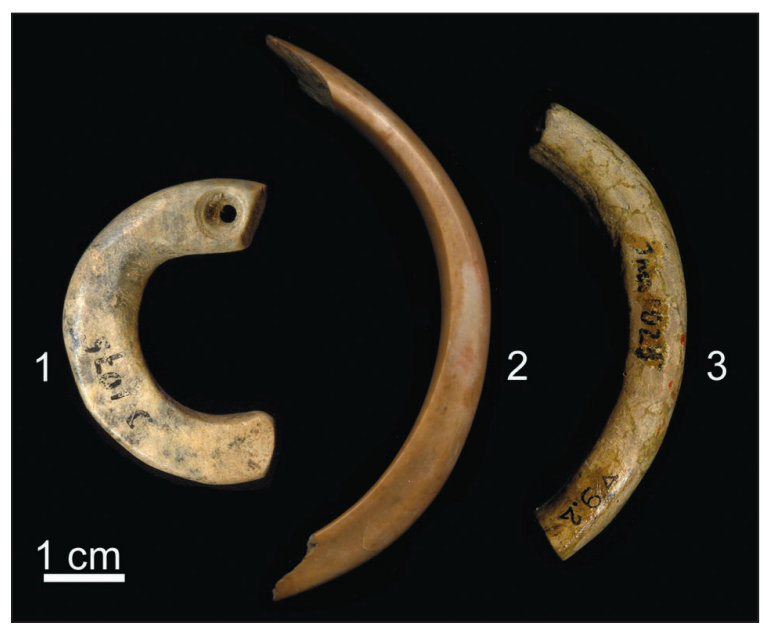

Fig. 9. Bone and clay ornaments: 1. bone pendant perforated at one end; 2. bone bracelet, 3. clay bracelet.

Elderfield 1990) point to the Mediterranean origin of these shells, and are usually taken to confirm their Aegean biotope. 13

However, the highest concentration of Spondylus finds is found along the Black Sea coastal zone and upstream of the Danube River in central Europe. This fact, presented for the first time more than 50 years ago (Clark 1952; Vencl 1959), even today suggests to some archaeologists the possibility that these shells originate from the Black Sea (Chapman 1981; Todorova 2000; 2002). This explanation is not unfounded, since the strontium isotope analyses previously undertaken can indicate only that the Spondylus shell cannot be found in the Black Sea today (Renfrew and Shackleton 1979; Shackleton and Elderfield 1990), while the possibility remains that Spondylus existed here during the Neolithic and Eneolithic periods. In the course of the $6^{\text {th }}$ and $5^{\text {th }}$ millennia, the temperature of the Black Sea was higher than it is today (Todorova 1995.56; 2002; 2000. 416-417), and new strontium isotope analyses of an enlarged sample of finds suggest the existence of at least two biotopes of the Spondylus and Glycymeris shells (Todorova 2002.184-185, Abb. 209). One of these biotopes is most definitely in the Mediterranean Sea. But, where is the other biotope?

The collection of marine shells from Vinča shows that, apart from bracelets, pendants and beads made of Spondylus, large quantities of bracelets made of Glycymeris shells were also imported into the central and northern Balkans. Are the objects of Glycymeris and Spondylus shells at the type-site of the
Vinča culture of the same origin? It seems that these genera were used in different periods, and it is possible that they were not part of the same exchange network. The role of Glycymeris shells in European prehistory is not well known, and these finds are not easily distinguished from those made of Spondylus. At the same time, the pattern of their distribution corresponds to Spondylus: unworked shells and artifacts can be found in the coastal stretch of the Adriatic and the Aegean Seas, while only artifacts are found in the Black Sea zone. By analyzing finds made of both species, as well as by analyzing other exotic goods, we should be in a position to determine their origin with more certainty.

Where is the place of origin of many artifacts made of marine species of shells that one finds at Vinča and other sites of the central and northern Balkans? And is there a noticeable difference in the frequency of Spondylus and Glycymeris finds? At most of the sites in the middle-Danube region, mostly only Spondylus finds have been found (Chapman 1981; Willms 1985; Dimitrijevic and Tripkovic 2003). On the other hand, on the basis of the collection of finds from Vinča, Glycymeris jewelry is plentiful, clearly outnumbering single specimens such as those detected at the Neolithic sites of Gura Baiucului, Botoš and Potporanj. Detailed future analyses of existing collections from other sites will surely reveal the presence of Glycymeris at many Neolithic sites, which is at the moment hinted by specimens from Anza (Gimbutas 1976.251, Fig. 215.6) and possibly Battonya - Parázstanya (Kalicz and Szénászky 2001.32, Abb. 4.1, Abb. 8.1, Abb. 9.1).

In sum, apart from Spondylus, jewelry (primarily bracelets) made of Glycymeris shells were exported in large quantities into Europe. However, at Vinča one might notice a diachronic change in the use of Spondylus and Glycymeris, which can certainly be expected at other Vinča culture sites in the future. It may come as a surprise that the settlers of Vinča imported bracelets made of Glycymeris at the end of the $6^{\text {th }}$ millennium $\mathrm{BC}$, which differs from the available evidence of the Aegean areas. For instance, in Sitagroi and other Aegean sites, mainly bracelets made of Spondylus were produced at the end of the $6^{\text {th }}$ and through the end of the $5^{\text {th }}$ millennium BC (Nikolaidou 2003; Müller 1997). Hence, in the light of these facts one can question the exclusively Aegean origin of the Vinča finds. What is the solution to this contradiction?

13 One of those samples originates from the site of Vinča. 
A distribution map of goods that are of marine origin in the central and northern Balkans reveals that Spondylus finds are completely absent in the area of the Vinča culture's southern distribution (Fig. 10). The settlement of Anza in Ovče Polje (FYR of Macedonia), which is connected with northern Greece through the Vardar valley, is currently the northernmost site of the Vinča culture where large quantities of marine shells were found (Gimbutas 1976). In contrast, very extensive excavations in Valač (Tasić 1960), Žitkovac (Tasić 1958), Predionica (Glišić 1964), Fafos I and II (Jovanović 1961), Gradac (Stalio 1972), Crnokalačka Bara (Tasić and Tomić 1969) and many other sites did not uncover any marine shells (see Fig. 10).14 Other types of exotic goods, such as obsidian, which are frequently found at Vinča culture sites in the Danube region, are absent also from the collection of the aforementioned sites (Tripkovic 2004; Glišic 1968). These facts should not lead to a premature conclusion about the complete seclusion of the southern Vinča culture sites from the exchange networks of the time; it is possible that future research in these areas may alter this pattern. However, it is certain that most of the artifacts that are of marine origin found at Vinča and other sites in the Danube region were not distributed through this southern route. Not only in the Neolithic, but also in later periods, the areas of southern Serbia and Macedonia, apart from technology and pottery decoration, do not show evidence that there was close communication with the area of the Danube region. Despite previous suggestions about contacts through the Morava-Vardar valleys (Benac, Garašanin and Srejovic 1979.22; Garašanin 1998), the absence of exotic goods, including obsidian, shows that some barriers may have existed for the diffusion of exotic goods along this route.

An alternative possibility that could explain how this type of supply reached the communities of the Vinča culture in the Danube region might be contact with communities on the eastern Adriatic coast. This contact can be traced back to the Early Neolithic, i.e. the Starčevo-Impresso culture (Benac 1973; Perić 1996). Neolithic inhabitants of the Adriatic coast who possibly used prestigious jewelry made of these shells were very likely involved in exporting and distributing these objects into the middle-Danube region. One of these communities was revealed at the site of Obre II in central Bosnia, a settlement of the But- mir culture. Numerous Spondylus objects were found there, from unworked shells to final products (Benac 1971). Undeniable archaeological evidence exists which proves that communities from this area had contact with communities of the Vinča culture in the central Balkans and southern Pannonian Basin, as well as with Sopot-Lengyel culture communities between the Sava and the Drava Rivers (Perić 1995; Marijanovic 1980.29; Dimitrijević 1979.301303; Benac 1979.452). Reinforcing this point, one may notice that in the course of the $6^{\text {th }}$ and $5^{\text {th }}$ millennia $\mathrm{BC}$, the northern Balkans, including a large part of the Pannonian Plain, was an area of intensive communication, if judged on the basis of the distribution of exotic goods. Here, the exchange of exotic goods characterizes all of the aforementioned cultures (Tripković 2004).

However, these observations certainly do not solve the problem regarding the origin of Spondylus and Glycymeris finds in the Vinča culture. They point to the differences between southern and northern areas of the Vinča culture, and undermine the hypothesis that these finds came exclusively from the Aegean region. It is already a certainty that the import of these goods was in a large part made possible through contacts with Butmir communities in the western regions of the Balkans, directly or through intermediaries (Dimitrijević and Tripković 2003). However, this can only be a partial solution to the problem. While the existence of two different culture zones with specific types of Spondylus artifacts is positively documented (Müller 1997), there remains the possibility that the old hypothesis, that the origin of at least some of the Spondylus (and Glycymeris) finds was the Black Sea, may be confirmed in the future.

\section{Conclusion}

The marine shell collection at Vinča is the largest in the region of the central and northern Balkans. Although fossil shells are locally available, it was concluded that the majority of ornaments were made using recent shells obtained through trade with contemporaneous Neolithic communities. Two bivalve genera, Spondylus and Glycymeris, were identified, revealing an approximate proportion of 60:40. These are easily recognizable when complete valves are compared, but difficult to distinguish in highly mo-

14 At some sites in Velika Morava Valley, Divostin (No. 24 on the map - McPheron 1988.330, Fig. 11.5) and Drenovac (not mapped - Chapman 1981.380, Fig. 143.18) several shell items were recorded, but neither species nor fossil/recent origin were specified (see Dimitrijević and Tripković 2003.58). 


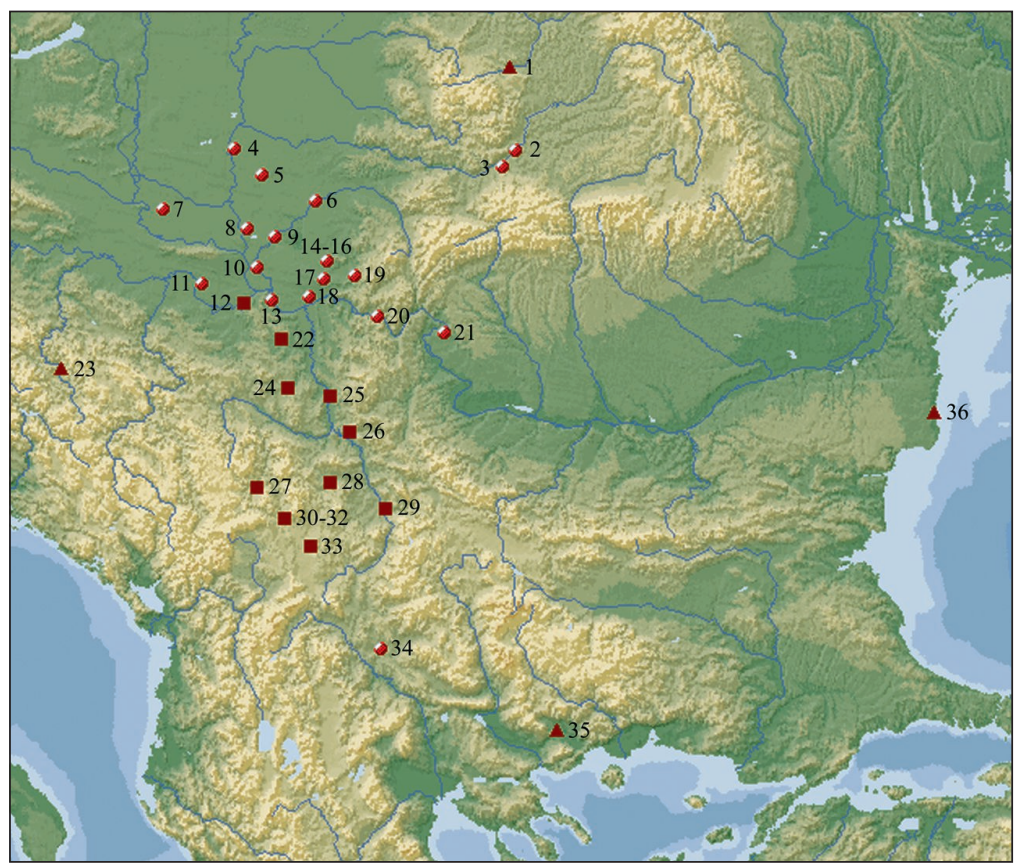

Fig. 10. Distribution of Spondylus/Glycymeris artifacts in the Central and North Balkans: • - Vinča culture sites, Spondylus/Glycymeris reported; - Vinča culture sites, Spondylus/Glycymeris not reported; ৯ - Non Vinča sites mentioned in the text. 1 - Gura Baciului; 2 - Alba Iulia; 3 - Tartaria; 4 - Novi Kneževac; 5 - Kikinda; 6 - Parta; 7 - Mostonga; 8 -Aradac; 9 - Botoš; 10 - Opovo; 11 - Gomolava; 12 - Jakovo; 13 - Vinča; 14 - Vršac, Kozluk; 15 - Vršac, At; 16 - Vršac, Potporanjske granice; 17 - Potporanj; 18 - Gaj, Čolak; 19 - Racasdia; 20 - Liubcova; 21 - Ostrovul Corbului; 22 - Selevac; 23 - Obre II; 24 - Divostin; 25 - Supska; 26 - Crnokalačka Bara; 27 - Naprelje; 28 - Pločnik; 29 - Gradac, Zlokućani; 30 - Žitkovac; 31 - Valač; 32 - Fafos; 33 - Predionica; 34 - Anzabegovo; 35 - Sitagroi; 36 - Durankulak.

dified items where shell morphology cannot be determined. This fact may be one of the reasons marine shell artifacts were identified as a priori Spondylus at many European sites and therefore their exchange pattern oversimplified. We presented distinguishing parameters for shell identification, particularly to differentiate ornaments manufactured from the Spondylus and Glycymeris genera, as well as those made of recent and fossil shells.

The distribution of Spondylus and Glycymeris items at Vinča is diachronic: Glycymeris items are more frequent in the earlier phases, while Spondylus items are more numerous in the later settlement phases. The variance in the types of ornaments is limited: bracelets, beads, pendants and garments were made from Spondylus, while from Glycymeris shell, only bracelets have been found. There are no indications of manufacturing within the settlement. Consequently, marine shell ornaments were probably brought to the settlement as final products. However, secondary modification of fragmented ornaments is evi- denced by perforations made on many bracelet fragments. This secondary treatment of the broken ornaments illustrates the value of the raw material from which they were made.

The direction from which items made of Spondylus and Glycymeris were brought to Vinča and other sites in the middle Danube is not very clear. There are three possible source areas: the Aegean, the Adriatic and the Black Sea. Production, intensive usage and exchange is proven by rich ornament assemblages at many sites within the Aegean region. In addition, this is the only region where shell ornament workshops have been identified. However, exchange routes are not well outlined. In the southern part of the distribution area of the Vinča culture, in the Velika and Južna Morava valleys, and in Kosovo, where many sites have been explored, Spondylus and Glycymeris items were not found. Also, diachronic distribution of the two genera evidenced at Vinča does not seem to appear at Aegean sites. Another possible Mediterranean source area is the Adriatic. Exchange with the Adriatic region is highly probable, according to well established connections recognized in general features of the material cultures between Neolithic communities in that region and the central Balkans. However, few of the sites with marine goods that have been recorded preclude any further evaluation of the development of the exchange network from this direction. Finally, considering the possibility of the Black Sea origin, the important facts are intensive usage of marine goods in this region and well-outlined exchange routes. A large number of sites with recorded marine goods are clustered along the Danube, from the Black Sea coast to Vinča, and further north and west. Workshops, however, have not been evidenced in this region. Further, the question remains whether Spondylus and Glycymeris inhabited the Black Sea in the Neolithic at all. Was this sea too cold for their survival?

It is possible, and even probable, that there was more than one source area for acquiring marine 
shells in specific periods of time, and that exchange routes changed through time. It is also quite possible that the manufacture and exchange of products made of these two mollusk genera, Spondylus and Glycymeris, as well as other marine goods, were not simultaneous. Only the accumulation of data from many European prehistoric sites with marine goods will enable the prehistoric exchange network with its roads of communication and trade to become visible.

\section{REFERENCES}

ANTONOVIĆ D. 1992. Predmeti od glačanog kamena iz Vinče. Centar za arheološka istraživanja. Beograd.

AVRAMOVA M. 2002. Der Schmuck aus den Gräbern von Durankulak. Durankulak. Die Prähistorischen Gräberfelder von Durankulak, Band II. Deutsches Archäologisches Institut, Sofia-Berlin: 191-206.

BABOVIĆ L. 1984. Orudje i oružje od kosti i rožine. In D. Srejović et al. (eds.), Vinča u praistoriji i srednjem veku. Galerija SANU, Beograd: 117-120.

BAR-YOSEF D. 1991. Changes in the Selection of Marine Shells from the Natufian to the Neolithic. In 0. Bar-Yosef and F. R. Valla (eds.), Natufian Culture in the Levant. International Monographs in Prehistory. Ann Arbor, Michigan: 629-636.

BAR-YOSEF D. 2002. From Statue Decoration to Floor Foundation: The Role of Glycymeris in the Levant. Paper read at ICAZ meeting. Durham, 24-28 August 2002.

BENAC A. 1971. Obre II - neolitsko naselje butmirske grupe na Gornjem polju. Glasnik Zemaljskog Muzeja 26: 5300.

1973. Obre I - neolitsko naselje Starčevo-impreso i kakanjske kulture na Raskršću. Glasnik Zemaljskog Muzeja 27(28): 5-171.

1979. Prelazna zona. In A. Benac (ed.), Praistorija jugoslavenskih zemalja 2. Neolit. ANU BiH, Centar za balkanološka istraživanja, Sarajevo: 363-472.

BENAC A., GARAŠANIN M., SREJOVIĆ D. 1979. Uvod. In A. Benac (ed.), Praistorija jugoslavenskih zemalja 2. Neolit. ANU BiH, Centar za balkanološka istraživanja, Sarajevo: $11-31$.

CHAPMAN J. 1981. The Vinča Culture of South-East Europe. Studies in chronology, economy and society. British Archaeological Reports IS 117, Oxford.

CHILDE G. V. 1929. The Danube in Prehistory. Clarendon Press. Oxford.
1957. The Dawn of European Civilization. Routledge and Kegan Paul Ltd. London.

CLARK J. G. D. 1952. Prehistoric Europe. The Economic Basis. Methuen. London.

DIMITRIJEVIĆ S. 1979. Severna zona. In A. Benac (ed.), Praistorija jugoslavenskih zemalja 2. Neolit. ANU BiH, Centar za balkanološka istraživanja, Sarajevo: 229-362.

DIMITRIJEVIĆ V., TRIPKOVIĆ B. 2003. New Spondylus Findings at Vinča, Belo Brdo: 1998-2001 Campaigns and Regional Approach to Problem. Starinar 52: 47-62.

GARAŠANIN M. 1979. Centralnobalkanska zona. In A. Benac (ur.), Praistorija jugoslavenskih zemalja 2. Neolit. ANU BiH, Centar za balkanološka istraživanja, Sarajevo: $79-212$.

1998. Vinčanska kultura i njeni uticaji. In N. Tasić (ed.), Arheološko blago Kosova i Metohije. SANU, Beograd: 57-87.

GAYDARSKA et al. 2004. Breaking, Making and Trading: the Omurtag Eneolithic Spondylus Hoard. Archaeologia Bulgarica 8 (2): 11-34.

GIMBUTAS M. 1976. Ornaments and Other Small Finds. In Gimbutas M. (ed.), Neolithic Macedonia. As reflected by excavation at Anza, Southeast Yugoslavia. Monumenta Archaeologica 1. The Institute of Archaeology, The University of California, Los Angeles: 242-256.

GLÄSER R. 1996. Zur absoluten Datierung der Vinča-Kultur anhand von C-Daten. In F. Draşovean (ed.), The Vinča Culture, ist Role and Cultural Connections. Museum Banaticum Temesiense: 141-162.

GLIŠIĆ J. 1964. Stratigrafija naselja Vinčanske grupe kod Predionice u Prištini. Glasnik Muzeja Kosova i Metohije 7-8: 11-61.

1968. Ekonomika i socijalno ekonomski odnosi u neolitu podunavsko-pomoravskog basena. In L. Trifunović (ed.), Neolit centralnog Balkana. Narodni muzej, Beograd: 21-61. 
HOERNES M. 1870. Die fossilen Molluscen des Tertiarbeckens von Wien. Abhandlungen d. k. Geol. Reichanst IV: $1-279$.

JOVANOVIĆ B. 1961. Stratigrafija naselja Vinčanske grupe kod Kosovske Mitrovice. Glasnik Muzeja Kosova i Metohije 6: 9-78.

KALICZ N., SZÉNÁSZKY J. 2001. Spondylus-Schmuck im Neolithikum des Komitats Bekes, Südostungarn. Praehistorische Zeitschrift 76 (1): 24-54.

KARALI L. 1999. Shells in Aegean Prehistory. British Archaeological Reports IS 761. Archaeopress, Oxford.

KOJUMDGIEVA E., STRACHIMIROV B. 1960. Les Fossiles de Bulgarie. VII Tortonien: 1-317.

LAZAROVICI G., MAXIM Z. 1995. Gura Baciului. Monografie arheologica. Muzeul National de Istorie a Transilvaniei. Cluj-Napoca.

MARIJANOVIĆ B. 1980. 0 položaju privjezaka od Spondylusa iz Obra. Glasnik Zemaljskog Muzeja 34: 27-33.

McPHERRON A. 1988. Miscellaneous Small Artifacts. In A. McPherron and D. Srejović (eds.), Divostin and the Neolithic of Central Serbia. Ethnology Monographs 10. University of Pitsburgh, Department of Archaeology, Pitsburgh: 325-336.

MILLER M. 2003. Technical Aspects of Ornament Production at Sitagroi. In E. S. Elster and C. Renfrew (eds.), Prehistoric Sitagroi: Excavations in Northeast Greece, 19681970, Volume 2: Final Report. Monumenta Archaeologica. University of California, Cotsen Institute of Archaeology, Los Angeles: 369-382.

MÜLLER J., HERRERA A., KNOSSALLA N. 1996. Spondylus und Dechsel-zwei gegensätzliche Hinweise auf Prestige in der mitteleuropäischen Linearbandkeramik? In J. Müller and R. Bernbeck (eds.), Prestige - Prestigegüter - Sozialstrukturen. Beispiele aus dem europäischen und vorderasiatischen Neolithikum. Archäologische Berichte 6: 8196.

MÜLLER J. 1997. Neolithische und chalkolithische Spondylus-Artefakte. Anmerkungen zu Verbreitung, Tauschgebiet und sozialer Funktion. In C. Becker, M. L. Dunkelmann, C. Metzner-Nebelsick, H. Peter-Röcher, M. Roeder and B. Teržan (eds.), Xrovos. Beiträge zur prähistorischen Archäologie zwischen Nord- und Südosteuropa. Festschrift für Bernhard Hänsel. Verlag Marie Leidorf Gmbh, Espelkamp: 91-106.

NEWELL N. D. 1969. Family Glycymerididae Newton, 1922. In R. C. Moore and C. Teichert (eds.), Treatise on Invertebrate Paleontology, Part N, Volume 1, Mollusca 6, Bi- valvia. The Geological Society of America Inc., The University of Kansas: 267-269.

NIKOLAIDOU M. 2003. Items of Adornment. In E. S. Elster and C. Renfrew (eds.), Prehistoric Sitagroi: Excavations in Northeast Greece, 1968-1970. University of California, Cotsen Institute of Archaeology, Los Angeles. Volume 2: 331-360.

PERIĆ S. 1995. Butmirska kultura. Geneza i razvoj. Arheološki institut. Beograd.

PETKOVIĆ K. (ed.) 1987. Fosili Srbije - registar, Geologija Srbije, V-2. Univerzitet u Beogradu, Zavod za regionalnu geologiju i paleontologiju Rudarsko-geološkog fakulteta. Beograd.

PETROVIĆ J. 1997. Neolit. In Lj. Cerović (ed), Muzej Vojvodine. Muzej Vojvodine, Novi Sad: 22-34.

RAŠAJSKI J. (ed.) 2002. Gradski Muzej Vršac. Gradski Muzej Vršac. Vršac.

REESE D. S. 1987. Marine and Fresh-water Molluscs. In P. Hellström (ed.), Paradeisos. A Late Neolithic settlement in Aegean Thrace. Medelhavsmuseet Memoir 7, Stockholm: 9-39.

RENFREW C., SHACKLETON N. 1979. Neolithic Trade Routes Realigned by Oxygen Isotope Analyses. In C. Renfrew (ed.), Problems in European Prehistory. Edinburgh University Press, Edinburgh: 183- 189.

SÉFÉRIADÈS M. L. 1995. Spondylus Gaderopus: The Earliest European Long Distance Exchange System. Poročilo o raziskovanju paleolitika, neolitika in eneolitika $v$ Sloveniji 22: 238-256.

1995b. La route néolithique des Spondylus de la Méditerranée a la Manche. Nature et Culture, Colloque de Liège (13-17 decembre 1993), ERAUL 68: 291-358.

2000. Spondylus Gaederopus: Some Observations on the Earliest European Long Distance Exchange System. In S. Hiller and V. Nikolov (eds.), Karanovo III. Beiträge zum Neolithikum in Südosteuropa. Phoibos, Wien: 423-437.

SHACKLETON J., ELDERFIELD H. 1990. Strontium isotope dating of the source of Neolithic European Spondylus shell artefacts. Antiquity 64 (243): 312-314.

SHACKLETON N. J. 2003. Preliminary Report on the Molluscan Remains at Sitagroi. In E. S. Elster and C. Renfrew (eds.), Prehistoric Sitagroi: Excavations in Northeast Greece, 1968-1970, Volume 2. University of California, Cotsen Institute of Archaeology, Los Angeles: 361-365. 
SREJOVIĆ D., JOVANOVIĆ B. 1959. Oruđe i oružje od kosti i nakit iz Vinče. Starinar IX-X: 181-190.

STALIO B. 1972. Gradac. Praistorijsko naselje. Narodni Muzej. Beograd.

STEVANOVIĆ M., JOVANOVIĆ B. 1996. Stratigraphy of Vinča - Belo Brdo Reconsidered. Starinar 47: 193-204.

STEVANOVIĆ P. 1977. Miocen okoline Beograda. In K. Petković (ed.), Geologija Srbije, II-3, Stratigrafija, Kenozoik. Univerzitet u Beogradu, Beograd: 357-393.

TASIĆ N. 1958. Žitkovac i neki problemi relativnog hronološkog odnosa neolitskih i eneolitskih naselja na Kosovu i u dolini Ibra. Glasnik Muzeja Kosova i Metohije 3: 11-50.

1960. Završna istraživanja na praistorijskom naselju kod Valača. Glasnik Muzeja Kosova i Metohije 4-5: 11-82.

TASIĆ N., TOMIĆ E. 1969. Crnokalačka Bara. Naselje starčevačke $i$ Vinčanske kulture. Dissertationes VIII. Arheološko društvo jugoslavije, Narodni Muzej. Beograd.

THEOCHARIS D. 1973. Neolithic Greece. National Bank of Greece. Athens.

TODOROVA H. 1995. Bemerkungen zum frühen Handelsverkehr währen des Neolithikums und des Chalkolithikums im westlichen Schwarzmeerraum. In B. Hänsel (ed.), Handel, Tausch und Verkehr im Bronze- und Früheisenzeitlichen Südosteuropa. Dr. Rudolf Habelt Gmbh. MünchenBerlin: 53-65.

2000. Die Spondylus-Problematik heute. In S. Hiller and V. Nikolov (eds.), Karanovo III. Beiträge zum Neolithikum in Südosteuropa. Phoibos, Wien: 415-422.
2002. Die Mollusken in den Gräberfeldern von Durankulak. Durankulak. Die Prähistorischen Gräberfelder von Durankulak, Band II. Deutsches Archäologisches Institut, Sofia-Berlin: 177-186.

TRIPKOVIĆ B. 2004. Obsidian Deposits in the Central Balkans? Tested against archaeological Evidence. Starinar 53-54: 163-177.

TSUNEKI A. 1989. The Manufacture of Spondylus shell objects at Neolithic Dimini, Greece. Orient 25: 1-21.

VASSITS M. 1910. Die Hauptergebnisse der prähistorischen Ausgrabung in Vinča im Jahre 1908. Praehistorische Zeitschrift 2(1): 7-16.

VASIĆ M. 1932. Preistorijska Vinča I. Industrija cinabarita $i$ kosmetika u Vinči. Izdanje i štampa Državne štamparije Kraljevine Jugoslavije. Beograd.

1936a. Preistorijska Vinča II. Oblici grobova. - Mistične oči. - Igra na tabli. - Datovanje Vinče. Izdanje i štampa Državne štamparije Kraljevine Jugoslavije. Beograd.

1936b. Preistorijska Vinča III. Plastika. Izdanje i štampa Državne štamparije Kraljevine Jugoslavije. Beograd.

1936c. Preistorijska Vinča IV. Keramika. Izdanje i štampa Državne štamparije Kraljevine Jugoslavije. Beograd.

VENCL S. 1959. Spondylove šperky v podunajskem neolitu. Archeologické rozhledy XI (5): 699-741.

VLASSA N. 1976. Neoliticul Transilvaniei. Studii, articole, note. Bibliotheca Musei Napocensis III. Cluj-Napoca.

WILLMS C. 1985. Neolithischer Spondylusschmuck. Hundert Jahre Forschung. Germania 65 (2): 331-343. 